\title{
Impact of Business Risk on Corporate Capital Structure of Publicly-Listed Nigerian Companies
}

\author{
Dauda Mohammed \\ Department of Business administration and Entrepreneurship Bayero University, P.M.B 3011 Kano Nigeria
}

\begin{abstract}
This paper demonstrates the extent to whichchanges in business risk helppredictthe capital structure choices of Nigerialisted companies. The findings support a U-shaped function between earnings volatility and total debt ratio. In normal times when the threat of insolvency is low, firms cut their average rate of borrowing relative to total assetsby between 1 and 4 percent a year. However, they raised it by between 5 and 22 percent during periods of heightened market anxiety. This suggests that policies whichlower the expected bankruptcycosts relativeto company value will discourage an unnecessary use of debt.
\end{abstract}

Keywords: Capital structure, Industry effects, Business risk, Cashflow, Volatility, Nigeria

\section{Introduction}

A basic concept in corporate finance is that the market value of a firm is equal to the present value of its expected future free cashflows discounted by its weighted average cost of capital. Managers can increase free cashflows and consequent company market value through good capital budgeting and operating decisions. However, to assist with these decisions, it will be necessary for managers to work out the appropriate balance between debt and ordinary share capital in the firm's financial structure. Typically, financing with debt increases the common stockholder's expected rate of return on capital provided to profitable enterprises. But, as debt levels rise, the firm's earnings attributable to shareholders become more volatile due to the need to pay increasing amounts of interest before dividends. Such drives up the default risk premium on equity, lowering the estimate of the firm's market value.

In an attempt to understand how the trade-off between risk and returns affects the value of the firm, researchers have put forward a number of theories which have been subjected to empirical tests. The first of these hypotheses was developed in 1958 by Franco Modigliani and Merton Miller (hereafter referred to as MM) with a follow-up paper in 1963. According to MM, capital structure choices have no noticeable impact on a firm's economic value, assuming that there are no anticipated bankruptcy and information costs. However, the relaxation of the assumption of no expected bankruptcy-related problems in subsequent papers meant that firms whose free cashflows are more variable face a greater chance of insolvency and therefore should use less debt than those with stable earnings, ceteris paribus. Furthermore, the existence of asymmetric information creates an environment in which companies with credibly bright prospects will prefer to convey this knowledge to the market through new debt offerings with an associated increase in their gearing ratios.

Although some progress has been made on the capital structure puzzle, the theories that have emerged are imprecise, unwieldy and often offer completely opposing views. Moreover, the empirical evidence of the different models is largely confined to firms in industrialised countries with well-functioning credit markets and tax systems together with legal and regulatory structures as is subsumed under the original MM hypotheses.

This paper contributes to the literature in three important ways:

First, it investigates whether variations in business risk helps predict, or Granger-causes a change in the capital structure of ninety-four publicly-listed firms in Nigeria over the 2000 to 2006 period using a dynamic panel data framework. The aim is to test the power of the various capital structure models regularly cited in the literature in explaining the borrowing behaviour of Nigerian corporations in the first six years of the $21^{\text {st }}$ Century.To the best of our knowledge, this is the first paper to consider the leverage effect of earnings volatility for such a large panel of firms listed on the stock exchangeof an oil-dependent emerging market economy.Besides, Nigeria is the most populous country in Sub-Saharan Africa with ethnic groups, as well as economic and institutional structures that are very different to those in the Western world where research to date has been focused.

Second, it tests the hypothesis that the relationship between business risk and corporate leverage is nonlinear, initially decreasing and eventually rising in the U-shaped manner originally predicted by DeAngelo and Masulis (1980), Castanias (1983) and Kale et al (1991). The intuition underpinning this idea is that in deciding on the appropriate debt-equity ratio that companies should aim to achieve, analysts should consider the "psychology" of investors and its implication for the potential costs of financial distress relative to the firms'market value. Behavioural financial theoristshave argued that firms will face declining ratios of expected 
Impact of Business Risk on Corporate Capital Structure of Publicly-Listed Nigerian Companies

direct costs of bankruptcy ${ }^{1}$ to theirmarket valuesduring normal trading conditions when the threat of liquidation is low (James, 1991; Berger, 1995a and b).A decreasing proportion of such potential bankruptcy-related costs will, in turn, imply a declining equity risk premium, with a corresponding reduction in the use of financial leverage by firms. Conversely, an increasingratio of anticipated insolvency-related costs to company value is projected in periods when investors are very fearfulabout future market conditions. Key employees are more likely to abscond, suppliers more reluctant to extend credit as insolvency threatens. Common stockholders in particular willdemand a commensurate addition inthe risk premium, which suggests that the use of financial leverage by firms with good credit ratings will be high in abnormal business times.

Third, we check the robustness of the hypothesised U-shaped relationship between corporate leverage and business riskto a joint addition of an intercept dummy and a slope dummy interaction variable for industry affiliation. In this extended quadratic function, the business risk attribute has a differential effect on the borrowing choices of firms classified as manufacturing under the United Nations Standard Industrial Classification Code (SIC).

The paper is organised as follows: Section 1 briefly reviews theempirical evidence on corporate capital structure.Section 2 describes our data.Section 3 specifies the empirical model and proxies. Section 4presents the basic regression results. Section 5tests their robustness to industry classification. The final section provides concluding remarks and recommends policies which might help reduce the share of potential bankruptcy-related costs in total firm assets and hence discourage unnecessary use of debt financing.

\section{Literature Review}

The general consensus among academics and practitioners is that the original work of Modigliani and Miller in the late 1950s and earlier 1960s marked the start of modern capital structure research (Bradley et al, 1984,Harris and Raviv, 1990 and 1991, Myers, 2003,Brigham and Ehrhardt, 2005 and Arnold, 2008). This is in spite of the fact that some of the MM assumptions have attracted a good deal of criticismfor being unrealistic and unrepresentative of the real business world.Consequently, subsequent financial researchers have focused on relaxing the $\mathrm{MM}$ assumptions in order to produce a more plausible explanation for the observed financing behaviour of firms. For brevity, our review of these papers is limited to a summary of theresults of the empirical literature on the determinants ofcorporate borrowing decisions. Comprehensive surveyscan be found in Bradley et al (1984), Taggart (1986), Masulis (1988), Titman and Wessels (1988), Harris \&Raviv (1991), Homaifaret al (1994), Graham and Harvey (2003) andMyers ( 1984 and 2003).

The bulk of the empirical research on capital structure has focused on the behaviour of firms in the United States and other G-7 states with similar institutional structures andby implication their market values. The major contributors are Taggart (1977), Ferri and Jones (1979),Bowen, et al (1982), Marsh (1982), Bradley et al (1984), Jalilvand and Harris (1984), Castanias (1983), Long and Malitz (1985), Auerbach (1985), Kester (1986), Titman and Wessels (1988), Hodder and Senbet (1990), Chung (1993), Rajan and Zingales (1995), Wald (1999), Shyam-Sunder and Myers (1999), Ozkan (2001)and Bevan and Danbolt (2002).

The basic stylized facts unearthed by these studies are that firms within an industry tend to have similar gearing ratios and that they retain their relative debt-equity ratio rankings over time. Leverage ratios of specific industries were documented by Bowen, et al (1982), Bradley et al (1984), Long and Malitz (1985) and Kester (1986).Their results showed that in line with the traditional pecking order theories, innovative industries, such as Drugs, Electronics and Food industries, have had consistently low leverage ratios by comparison with mature and highly regulated industries such as Utilities and Airlines. Additionally, studies by Bradley, et al (1984), Castanias(1983), Long and Malitz (1985), Kester (1986), Marsh (1982) and Titman andWessels (1988) on the effect of firm-specific factors generally agreed that the use of debt financing is a positive function of fixed assets, non-debt tax shields and growth opportunities. They found a negative correlation between leverage and earnings volatility, advertising expenditures, bankruptcy probability, profitability and the uniqueness of the firm's product. There are conflicting results on the relationship between firm size and leverage. For example, while studies by Ferri and Jones (1979) and Chung (1993) found no evidence in support of an association between size and corporate capital structure decisions, Homaifaret al (1994) and Titman and Wessels (1988) reportedresults which were consistent with the notion that larger firms have higher debt ratios.

Another prominent area of research in the empirical literature focused on the factors determining the speed with which firms adjust towards a target or optimum debt ratio as predicted by the static trade-off theory of capital structure. Taggart (1977) was among the earliest researchers to provide evidence that the speed with which firms reverted to their optimum debt levels was primarily dependent on their proportions of liquid assets and short-term debt instruments. Marsh (1982) argued that companies have long-term target debt levels, although they deviate from these targets in the short-run in response to capital market conditions. The decision to correct for imbalances between current and target long-term debt levels were influenced by operating risk,

\footnotetext{
${ }^{1}$ Expected bankruptcy costs is normally defined as the product of probability of insolvency and the deadweight
} liquidation costs that must be incurred by investors in the event of a company failure. 
Impact of Business Risk on Corporate Capital Structure of Publicly-Listed Nigerian Companies

company size and asset composition. The robustness of these likely determinants of the speed of adjustment was further confirmed byJalilvand and Harris (1984), Auerbach (1985), Wanzenried (2006) andWolfgang and Wanzenried (2006). They suggested that in addition to firm size, interest rates and stock priceswere other factors affecting the speed with which corporate leverage revert to equilibrium. Furthermore, Shyam-Sunder and Myers (1999) reported that these debt target adjustment models were superior to the conventional Myers-Majluf pecking order theories. The results of the work of Ozkan (2001) and Frank and Goyal (2003 and 2004) lend support to the dominance of these capital structure adjustment models. They showed that firms strive to maintain a long-term target debt ratio andthat managers undo the effects of shocks in the market, causing their leverage ratios to revert to the target relatively quickly.

While the majority of research results concentrate on furthering our understanding of the financial behaviour of firms within and across developed economies, the study by Wiwattanakantang (1999) and Booth et al (2001) were among the pioneering works to test the explanatory power of these models in emerging markets. The case studies for India by Bhaduri (2002) and for China by Chen (2003) and Huang and Song (2006)also added to ourunderstanding of the determinants of capital structure in developing countries.

Booth et al (2001) provided the first cross-sectional study on the determinants of corporate capital structure choices across ten developing countries from 1980 to 1991. This paper provided evidence that the conclusions of a previous international comparative study by Rajan and Zingales (1995) on developed-country data were also true for emerging markets with more primitive institutional backgrounds. Specifically, the results predicted that the borrowing behaviour of listed firms in each country responded significantly to changes in their risk characteristics, including profitability, asset tangibility, size, tax status and the ratio of the market to book value of equity. Again, as in the Rajan and Zingales study, there was strong evidence that the average leverage ratio of firms within each of ten developing countries varied considerably, indicating that specific country attributes and macroeconomic policies which are not under the direct control of corporate managers matter as much as the firm risk characteristics commonly analyzed in earlier empirical papers.

\section{Data Description}

The articles surveyed in the previous section, for the most part, share the prediction that the leverage of companies within a country decreases with earnings volatility. However, interpretation of the empirical results was tempered somewhat by a lack of consistency in the choice of variable proxies. So in an effort to understand which variable measurements are most realistic for our study, we consider in more detail the basic features of our data from 2000 to 2006. The starting point of 2000 corresponds to year in which the Nigerian accounting system was reformed to ensure that companies prepared their financial statements according to the guidelines of the International Accounting Standard. The end point 2006 was the last year before the Nigerian election in April 2007. Anecdotal evidence shows that elections introduce an atypical degree of volatility in company earnings and investment plans. Such politically-induced uncertainties should be avoided in studies that intend to shed light on the extent to which theories derived from Western country business conditions provide convincing explanations for the leverage choices of Nigerian listed companies.

The primary data was obtained directly from the stock exchange and a host of financial regulatory bodies, including the Central Bank of Nigeria (CBN) and the Securities and Exchange Commission (SEC). To check the authenticity of data, we compared it with that made available by some of the companies on their respective web sites as required by Nigerian law. Further, we excluded firms with less than three years' of continuous time series data on any of the variables in the model between 2000 and 2006 . We also dropped companies that were cross-listed on both the domestic and overseas exchanges. This helps to avoid the confounding effect of differences in economic structure, exchange rates, legislation and the level of development of local and foreign markets. Consequently, the final sample of our study consists of an unbalanced panel data set comprising ninety-fourcompanies and 419 observations. All the companies are listed on the Lagos stock exchange and as a whole; they make up more than three-quarters of the shares traded on it ${ }^{2}$.

The objectives of this section are organised under two major headings. The first examines the trends in the mean value of the leverage ratio. The second presents the results of our contemporaneous pair-wise correlation analysis of the degree of correspondence of directional movement in leverage ratio annual changes and business risk.

\subsection{Trends in the mean leverage ratio}

The main variable of interest in this study is the leverage ratio of Nigerian firms defined as the book value of the sum of short and long-term liabilities (i.e., total liabilities) divided by total assets. It measures the percentage of funds provided by short-term, medium and long- term sources other than equity finance. The use of such a broad definition is in recognition of the fact that for many Nigerian firms, especially smaller ones with

\footnotetext{
${ }^{2}$ The list of companies included in our analysis is available from the author on request at: daudaknt@yahoo.co.uk
} 
Impact of Business Risk on Corporate Capital Structure of Publicly-Listed Nigerian Companies

limited access to stock and long-term debt markets, a combination of short and medium-term finance, including bank overdraft, trade credit, leasing and hire purchase, form the greater part of their funding requirements. Moreover, as noted by Chen (2003), the use of such book values helps avoid the limitations of missing information on the share of company stocks issued and openly traded on the stock exchange as well as on the gains in capital value arising from a dramatic rise in asset prices in many emerging markets, including Nigeria, from 2000 to 2006.

Figure 1 (Panels A and B) depicts the trend in our estimated mean of the ratio of total debt to assets from 2000 to 2006 for our entire panel of ninety-four listed companies and a sub-sample of manufacturing firms.The influence of industry affiliation on the capital structure choices of firms were rarely explicitly considered in previous empirical studies, despite their potentially valuable effects.

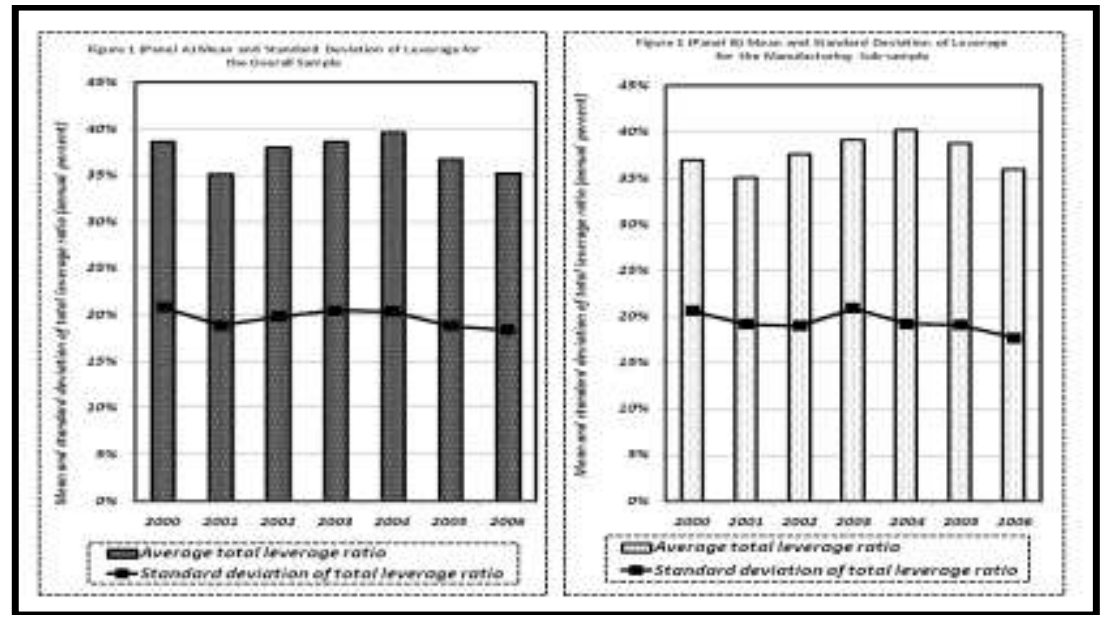

We note that between 2000 and 2001, oursub-group of sixty-two manufacturing firms experienced a small decline in their average total liabilities. They fell from 36 to a minimum of just under 35 percent of total assets. A similar pattern of reduction in the average leverage ratio was observed for our overall group of ninetyfour firms. The first two years of the $21^{\text {st }}$ Century was a time when Nigeria signed an IMF agreement to receive a debt-restructuring deal from the Paris Club and a $\$ 1$ billion credit from the IMF itself; both were allied to economic reforms (CIA Fact Book, 2010). Moreover, in 2001, the market for low-rated bonds, such as those issued byour Nigerian companies, dried up due to the terrorist attack on the World Trade Centre in New York. During this period, the interest rate on new bonds issues went up markedly, persuading firmsto sell stocks, even if they were undervalued.

From 2002 to 2004, the average leverage ratios for the overall panel and for our manufacturing firms rose from roughly 38 percent in 2002 to slightly more than 40 percent in 2004 . The start of this period corresponds to the date when Nigeria pulled out of its IMF debt relief programafter failing to meet its spending and exchange rate reform conditions. In addition, the Nigerian Government and its banks borrowed heavily on the basis of rising commodity prices and export earnings with associated economic growth. Thereafter, the leverage ratio declined consistently, presumably because of a renewed determination to implement the marketoriented reforms aimed at modernising the financial system, as well re-structuring and downsizing the public sector.To the extent that these reforms eased constraints in the stock market, they would have encouraged firms to sell new stocks to return their capital structure to their preferredtarget levels.

Indeed, descriptive statistics in Table Alin the Appendix show that the average leverage ratio of our manufacturing sub-sample wasbroadly comparable to the overall group average of 38 percent observed from 2000 to 2006. The T-test result shows a statistically insignificant difference between the mean debt ratio of the manufacturing and the overall sample. This is not surprising since statistics for the manufacturing sub-sample were based on a total of 282 annual time series observations which was roughly two-thirds of our total 418 observations used in the calculations for the overall panel.

Figure 2 (Panel A) plots the yearly changes in the natural logarithm of the total debt ratio. The series for the overall sample appears to be stationary with no persistent underlying trend between 2000 and 2006 . Despite this trend randomness at the aggregate level, the total leverage ratio annual changes for the period from 2002 to 2006 increasedconsistently for our sub-sample manufacturing firm, rising from minus 0.99 percent to plus 13.65 percent.Nevertheless, the summary statistics in Appendix Table A1 show that, on average,the total liabilities relative to the total assets of our group of manufacturing firms rose by 7 percent, which is significantly lower than the 11 percent reported for our panel of ninety-four firms. 


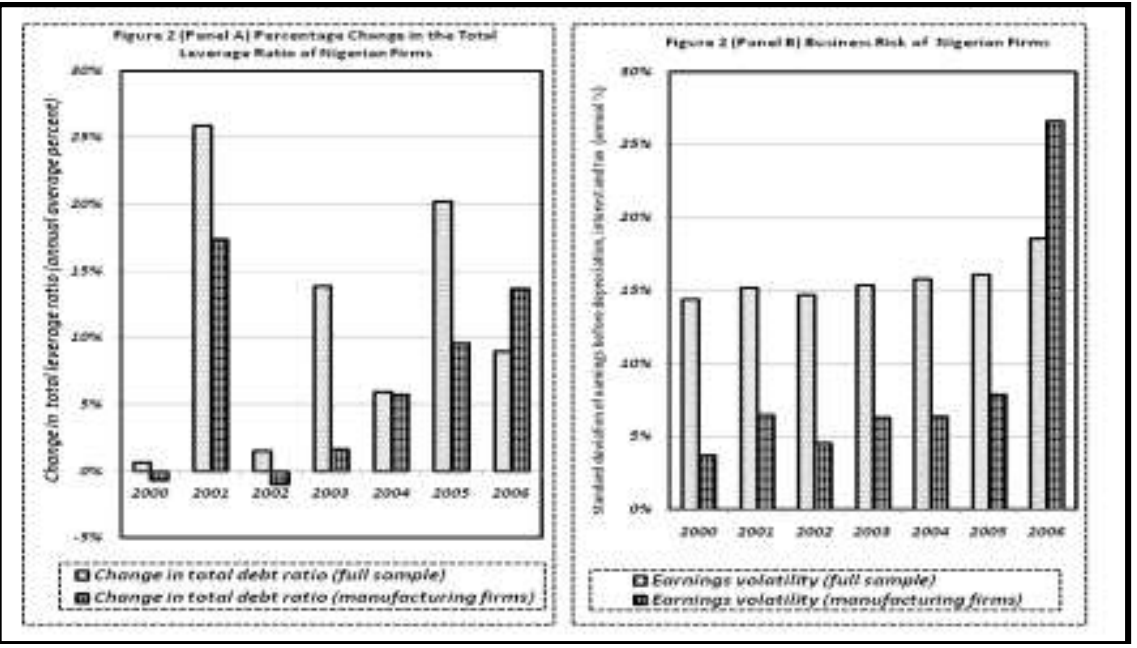

2.2: The correlation between the leverage ratio and business risk

An objective of this study is to investigate the relationship between observed changes in the leverage ratio and the business risk of Nigerian listed firms. We define business risk in terms of the standard deviation of the percentage change in operating income before depreciation, interest and tax, meaning that our indicator of earnings volatility is not directly affected by the firm's debt level.Figure 2 (Panel B) plots the estimated volatility of earnings for our full and sub-sample of manufacturing firms over the six years of study. In every year, the earnings risk for our average manufacturing firm is lower than the overall average for our ninety-four companies, except in the final year 2006. A possible reason for the more stable cashflow ofour manufacturing firms is that they tend to be larger and often more diversified.

In this section, therefore, we examine the validity of our theoretical prediction that firms with more variable cashflows (i.e., higher business risk) tend to use less debt finance relative to their total assets. But unlike the papers cited in the previous section, our aim here is to study this and other related issues through a descriptive analysis of the degree of similarity in the directional movements in the panel data for our total debt ratio and business risk as measured by the contemporary pair-wise correlations between them. A more detailed investigation of the robustness of the effect ofbusiness riskon the financing behaviour of our panel of Nigerian firms is conducted in an econometric study in Sections 4 and 5.

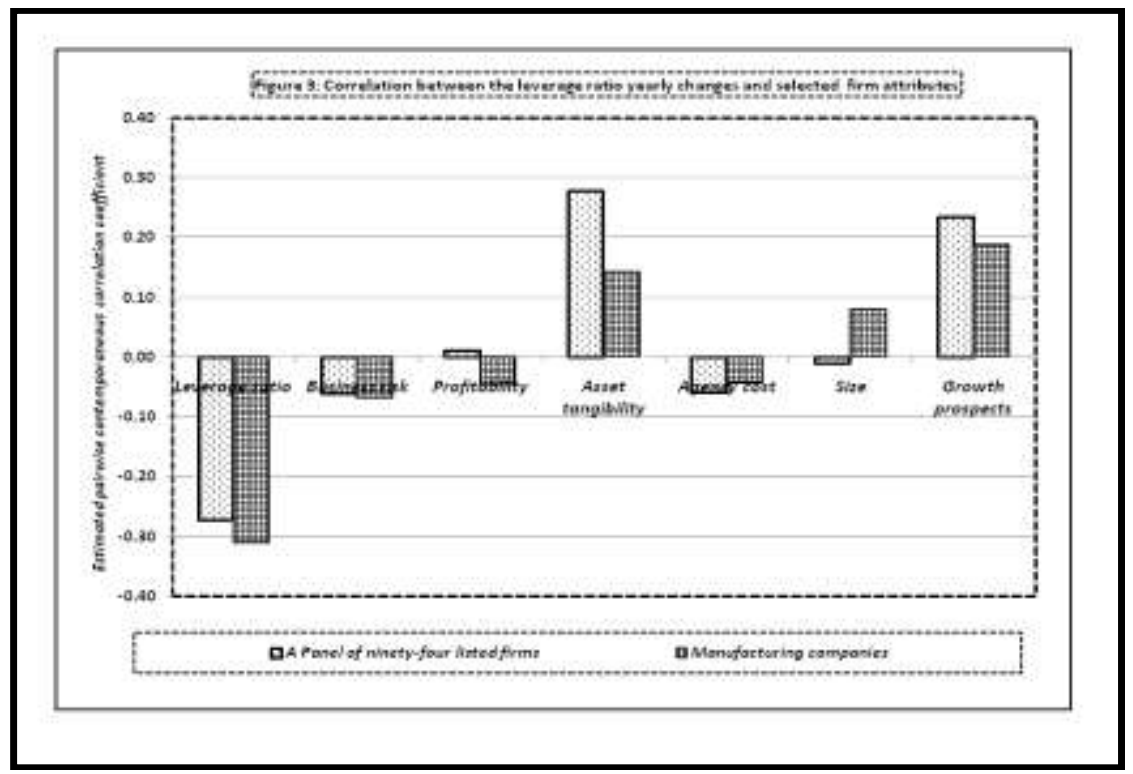

The estimates of the pairwise correlationbetween the annual changes in the total debt ratio and those major determinants frequently cited in the literature are presented in the Appendix Table A1. However, for ease of exposition, these contemporary correlation coefficients are also represented graphically in Figure 3 above. As expected, the correlation between total leverage ratio changes and earnings risk is a constantlynegative figure of minus 0.07 for both the sub-group of manufacturing firms and the whole sample of ninety-four firms, even though these scores were insignificantly different from zero at the conventional five percent level. 
There are three further observations in Figure 3 which are of particular interest with respect to the predictions of traditional optimal capital structure theories. First, it shows that the relationship between the total debt ratio changes and outstanding leverage levels, asset tangibility, agency costs and the future growth prospects of a company are consistent with the predictions of the trade-off theories. Second, the static trade-off theory of a positive correlation between profitability and the use of financial leverage is inconsistent with the behaviour of our group of manufacturing companies. For these firms, the problem of asymmetric information means that new capital is first raised internally by reinvesting net profits as suggested by the conventional Myers-Majluf pecking order models, although there is insufficient evidence to confirm the order with which external finance is garnered when the supply of internal funds is exhausted. Nevertheless, Frank and Goyal (2003) show that while theMyers-Majluf claim is widely held, the evidence is very sensitive to the time period and to how one corrects for missing data in an unbalanced panel. Third, the prediction of a positive leverage size effect is ambiguous. It seems to dependon the industry attributes of the firms in question. The features of a dynamic panelmodel which corrects for the bias induced by omittedvariables relating to industry classification are discussed in the next section.

\section{Empirical Specification and Proxies}

The existing theoretical literature does not provide a definitive guideline on how to determine a priori which functional form should be used when testing the relationship between corporate leverage and its major determinants including business risk. But, given that this paper predicts a U-shaped relationship between business risk and corporate leverage, we follow Castanias (1983), DeAngelo and Masulis (1980) and Kale et al (1991) in specifying a dynamic quadratic function which takes the general form outlined in equation 3.1 below.As was said earlier, in choosing the extra variables, we focus primarily on those factors whose correlations with the capital structure choices of firms within a country have been shown to be robust and statistically significant regardless of time period and method of analysis. They are: profitability, asset tangibility, agency cost, company size and its growth prospects. The specification underlying our empirical results in the next section is as follows:

$$
Y_{i t}=\mu+\alpha\left[D_{i t}\right]+\beta\left[S D E V_{i t}\right]+\theta\left[S D E V_{i t}^{2}\right]+\gamma\left[X_{i t}\right]+\varepsilon_{i t}-\varepsilon_{i t-1} \ldots \ldots \ldots \ldots \ldots \ldots(3.1)
$$

where $Y_{i}$ is the dependent variable for company $i$ in a given time period $t$. In our case this is the year-onyear change in the natural logarithm of the ratio of total leverage to total assets. Such differencing helps to address the problem of non-stationarity in data (Maukherjeeet al, 1998, Asteriou and Hall, 2007). The $\operatorname{symbol} D_{i t}$ is the vector of four annual lags of total debt ratios. Data was lagged for four years back to 2002 because prior to that it was sporadic.If the coefficients of the $D_{i t}$ lags are significantly different from zero, then past leverage ratios Granger-causes current corporate debt positions as predicted bythe static trade-off model. The symbol $S D E V_{i t}$ is the measure of business riskin the current year defined in terms of the year-on-year estimates of the standard deviation of earnings relative to total assets. These calculations were carried out using a simple GARCH $(1,1)$ modelwhich excludes all other explanatory variables in both the conditional variance and mean equations. Thus, unlike the earlier study by Kale et al (1991) which assumes constant variance, our GARCH $(1,1)$ model allows both the conditional mean and variance of a firm's cash flow to change over time with the effects of shocks to the general business environment.The symbol $X_{i t}$ is a $(\mathrm{k} \times 1)$ dimensional vector containing observations on the control variables to be added concurrently. Like the dependent variable, these additional variables are expressed in terms of the first difference of the natural logarithm of the relevant series. The term $\varepsilon_{i t}$ is the error term ${ }^{3}$.

The coefficients $\mu, \alpha, \beta, \theta$ and $\gamma$ are the parameters to be estimated. Where $\mu$ is the overall constant term. It equates to the mean of the percentage change in the total debt ratio for our typical Nigerian firm when the values of all the determinants in our modelremain unchanged. The sum of the alpha coefficients $\alpha$ on the lag leverage ratios helps predict the speed of reversion to meanwhen shocked (Ozkan, 2001). A value of the sum of the alpha coefficient between 0 and 1 indicates model stability. It also suggests that the impact of the previous debt ratios on the current borrowing decisions of our average firm is persistent, but will tend toregress to the target level over time. The adjustment coefficient $\pi$ which measures how much of the disequilibrium is corrected in each period is equal to $\left(1-\sum \alpha\right)$. Thus, a sum of the $\alpha$ coefficients that is close to zero, say 0.1 , suggests that 90 percent of the adjustment to equilibrium takes place within our timeframe of one year. Such a fast rate of correction is characteristic of a relatively competitive capital market.

Theoretically, we anticipate that the $\beta$ coefficient will have a negative sign (i.e., $\beta<0$ ) and the $\theta$ coefficient a positive $\operatorname{sign}($ i.e.,$\theta>0)$. The rationale is that in normal trading periods, the ratio of expected direct bankruptcy-related costs to the market value of the firmis projected to decrease, despite our anticipated increase inearnings variability. This implies that the impact of these prospectivefinancial distress costs on the

${ }^{3}$ The definition of variables is given in Appendix Table A2. 
Impact of Business Risk on Corporate Capital Structure of Publicly-Listed Nigerian Companies

equity risk premium of our firms may be negligible when the probability of failure is low. Such trivialincreases in the potential cost of equity willencourage our firms to lower the level of debt in their capital structures. The opposite is the case during periods of financial crisis when possibleliquidationcosts relative to the company's value areexpected to rise considerably.Investors, equity holders in particular, will only be prepared to buy securities if the rate of return is high enough to compensate for the greater risk of insolvency.Such leads to an undervaluation of shares. As a result, most firms that need to raise external finance during periods of heightened anxiety in the credit market will probably be forced to turn to banks which are better equipped than individual investors to screen out good from bad credit risks. This will cause a rise in the firm's debt proportions in total assets.

To provide a consistent estimation of dynamic panel data models, earlier researchers, Maukherjeeet al (1998), Attanasioet al, (2000), Hsiao (2003) and Greene (2002),recommended the use of a Generalised-Methodof-Moments (GMM) Instrumental Variable (IV) estimator when some of the explanatory variables are correlated with the error-terms and there are no cross-equation restrictions on the parameters in the model.But as noted by Greene (2002), an assumption of noheteroskedasticityand contemporaneous correlation in the residuals is only valid insystems consisting of a comparatively large number of cross section units and a relatively small number of periods.

The next sections present the results of equation 3.1 as estimated using the GMM-IV technique. In what follows, we adopt a stepwise approach beginning with the assumption that leverage and business risk form a simple two variable system without the need to control for other additional factors. We then add jointly the five explanatory variables whose leverage effects have been shown in previous empirical studies to influence the capital structure choice of firms within a country. Finally, we include simultaneously the intercept and slope dummies for industry classification while retaining those explanatory variables in the earlier models that are statistically significant. In all estimations, we report two diagnostic test statistics: (i) The first order autocorrelation in the differential error terms which are asymptotically distributed as standard normal $\mathrm{N}(0,1)$ under the null of no serial correlation in the original residuals ${ }^{4}$ and (ii) the Sargan test of over-identifying restrictions which is asymptotically distributed as chi-square under the null of instrument validity.

\section{The Empirical Results and Discussion}

Table 1 summarizes the results of our GMM-IV regressions using pooled cross-sectional annual time series data for our ninety-four listed firms from 2000 to 2006. The regressions were performed using EViews Version 6. Our argument here is conducted under the following headings: (i) A simple two-variable empirical model and (ii) A simple multivariate empirical model. Explanations in these paragraphs are based on an informed, but speculative filigree of cause and effect. They may, or may not trace what actually happened.

\section{1: A simple two variable empirical model}

Regression 1 in Column 1of Table 1 is a simple causality test with the total debt ratio annual changes as the dependent variable. It reports the results of a model in which the relationship between the debt ratio changes and earnings risk is presumed to be a simple bivariate system without the need to account for the impact of other determinants. The sum of the coefficients of the four earnings volatility lags(i.e., $\left.S D E V_{t-1}, S D E V_{t-2}, S D E V_{t-3}, S D E V_{t-4}\right)$ is large at 2.95, although a Wald's coefficient restriction test of the null hypothesis that the sum of such joint additions is equal to zero was not rejected at five percent. We may therefore infer that a higher variability in a firm's projected cash flow by itself does not Granger-cause or help predict its borrowing behaviour. This result is consistent with the findings of the papers by Ferri and Jones (1979), Flath and Knoeber (1980) and Titman and Wessels (1988) which

Table 1: Estimates of the Capital Structure Model (2000 to 2006)

Dependent variable: The change in the ratio of total debt to total assets (DLLEV)

Mean of dependent variable: $9.71 \%$

Number of observations: 363

Estimation method: The Generalized Method of Moments (GMM-IV)

${ }^{4} \mathrm{We}$ are unable to carry out a test for second order serial correlation due insufficient time series data. 
Impact of Business Risk on Corporate Capital Structure of Publicly-Listed Nigerian Companies

\begin{tabular}{|c|c|c|c|c|c|}
\hline $\begin{array}{l}\text { Independent }(x) \\
\text { variables }\end{array}$ & $\begin{array}{l}\text { Mean } \\
\text { values }\end{array}$ & $\begin{array}{l}\text { Column } 1 \\
\text { Reg. } 1\end{array}$ & $\begin{array}{l}\text { Column } 2 \\
\text { Reg. } 2\end{array}$ & $\begin{array}{l}\text { Column } 3 \\
\text { Reg.3 }\end{array}$ & $\begin{array}{l}\text { Column } 4 \\
\text { Reg.4 }\end{array}$ \\
\hline$D L L E V_{t-1}$ & $\begin{array}{c}11.25 \\
\%\end{array}$ & $\begin{array}{c}-0.138[- \\
0.194]\end{array}$ & $\begin{array}{c}-0.146[- \\
5.208]\end{array}$ & $\begin{array}{c}-0.078[- \\
2.581] \\
\end{array}$ & $\begin{array}{c}-0.111[- \\
4.073]\end{array}$ \\
\hline$D L L E V_{t-2}$ & 6.20 & $\begin{array}{c}-0.252[- \\
1.315]\end{array}$ & $\ldots$ & $\ldots \ldots$ & $\ldots .$. \\
\hline$D L L E V_{t-3}$ & 6.40 & $\begin{array}{c}-0.173[- \\
1.304] \\
\end{array}$ & $\ldots .$. & $\ldots \ldots$ & ........ \\
\hline$D L L E V_{t-4}$ & $8.73 \%$ & $\begin{array}{c}-0.700[- \\
0.552]\end{array}$ & $\begin{array}{c}0.047 \\
{[1.090]}\end{array}$ & $\begin{array}{c}\mathbf{0 . 2 5 0} \\
{[5.150]}\end{array}$ & $\begin{array}{c}\mathbf{0 . 2 5 8} \\
{[3.205]}\end{array}$ \\
\hline$S D E V$ & 14.96 & ........ & $\begin{array}{c}1.121 \\
{[4.579]}\end{array}$ & $\begin{array}{c}-0.852[- \\
22.24] \\
\end{array}$ & $\begin{array}{c}-3.507[- \\
29.81] \\
\end{array}$ \\
\hline$S D E V_{t-1}$ & 15.93 & $\begin{array}{c}0.011 \\
{[0.002]}\end{array}$ & ....... & $\ldots$ & $\ldots . .$. \\
\hline$S D E V_{t-2}$ & 15.59 & $\begin{array}{c}-1.030[- \\
0.443]\end{array}$ & $\ldots \ldots$ & $\ldots$. & ....... \\
\hline$S D E V_{t-3}$ & 15.01 & $\begin{array}{c}0.383 \\
{[0.039]}\end{array}$ & ........ & $\ldots .$. & ....... \\
\hline$S D E V_{t-4}$ & 14.86 & $\begin{array}{c}3.589 \\
{[0.134]}\end{array}$ & ........ & $\ldots .$. & ....... \\
\hline$S D E V^{2}$ & 3.55 & $\ldots .$. & ........ & $\begin{array}{c}\mathbf{5 . 3 9 5} \\
{[41.92]} \\
\end{array}$ & $\begin{array}{c}21.65 \\
{[17.24]} \\
\end{array}$ \\
\hline PROFITABILIT & $\begin{array}{c}- \\
27.32 \\
\%\end{array}$ & $\ldots .$. & $\begin{array}{l}-\mathbf{- 0 . 0 9 5}[- \\
5.159]\end{array}$ & $\begin{array}{c}-0.208[- \\
37.47]\end{array}$ & $\begin{array}{c}-0.055[- \\
5.552]\end{array}$ \\
\hline TANGIBILITY & 7.30 & $\ldots . .$. & $\begin{array}{c}\mathbf{0 . 1 0 4} \\
{[2.567]}\end{array}$ & $\begin{array}{c}\mathbf{0 . 0 6 6} \\
{[4.409]}\end{array}$ & $\begin{array}{c}-0.025[- \\
2.485]\end{array}$ \\
\hline GROWTH & 19.71 & ....... & $\begin{array}{c}\mathbf{0 . 0 0 3} \\
{[2.027]}\end{array}$ & $\begin{array}{c}0.002 \\
{[0.974]}\end{array}$ & $\begin{array}{c}0.006 \\
{[14.72]} \\
\end{array}$ \\
\hline$A G E N C Y$ COST & -11.08 & ....... & $\begin{array}{c}-0.271[- \\
5.972] \\
\end{array}$ & $\begin{array}{c}-0.241[- \\
4.374] \\
\end{array}$ & $\begin{array}{c}-0.220[- \\
7.857]\end{array}$ \\
\hline$S I Z E$ & 10.73 & $\ldots .$. & $\begin{array}{c}-0.288[- \\
4.574] \\
\end{array}$ & $\begin{array}{c}-0.113[- \\
1.139] \\
\end{array}$ & $\begin{array}{c}-0.086[- \\
0.746] \\
\end{array}$ \\
\hline$D U M M F$ & 1.00 & ...... & $\ldots$ & $\ldots \ldots$ & $\begin{array}{c}0.181 \\
{[6.598]}\end{array}$ \\
\hline$D U M M F * S D E$ & 10.53 & ....... & $\ldots$ & $\ldots \ldots$ & $\begin{array}{c}-10.39[- \\
5.392]\end{array}$ \\
\hline $\begin{array}{l}\text { Short-term effect } \\
\text { of business risk }\end{array}$ & & $\begin{array}{c}2.953 \\
{[0.840]}\end{array}$ & 1.121 & 9.94 & 29.40 \\
\hline $\begin{array}{l}\text { Long-term effect } \\
\text { of business risk }\end{array}$ & & $\begin{array}{c}1.304 \\
{[0.918]}\end{array}$ & 1.019 & 12.00 & 34.47 \\
\hline Correlation 1 & & 0.658 & 0.398 & 0.327 & 0.59 \\
\hline $\begin{array}{l}\text { Sagan test (p- } \\
\text { value) }\end{array}$ & & 19.54 & 88.66 & 87.33 & 55.01 \\
\hline
\end{tabular}

Notes: 1. Definitions of variables are given in Appendix Tables 2

2. The numbers in $[\ldots]$ are t-statistics

3. The estimated coefficients in bold italics are significant at the five percent confidence level.

4. Long-run effects are calculated as the estimated short-term effect divided by one minus the coefficient on the lagged leverage variable.

concluded that there is no significant causal relationship between corporate debt and business risk. But as Mikkelson (1984) and Berger (1995a) pointed out, this finding may be due to weaknesses in our two-variable linear function, in particular errors arising from omitted variables. Firms with highly irregular cashflows will need to consider the net effect of other factors determining the various potential costs and benefits associated with debt and equity financing. The firm-specific attributes that the different theories of capital structure suggest may offset the adverse effects of business risk are: growth prospects, profitability, non-debt tax shields, industry classification, the collateral value of assets and uniqueness. The ability of these features to distinguish among 
Impact of Business Risk on Corporate Capital Structure of Publicly-Listed Nigerian Companies

causal and spurious relations, as well as their influence on the total debt ratio changes of our average firm are discussed in the next section.

\section{2: A simple multivariate empirical model}

Column 3 of Table 1 presents the results for the basic (or restricted) multivariate quadratic capital structure model. For the most part, the coefficient estimatesare generally in accord with our a priori ideas about the direction of the impact of the selected firm attributes on the observed total debt ratio annual changes.

In particular, the measures representing earnings volatility appear to be correlated with the total debt ratio changes in our predicted U-shaped manner. As expected, the signs on theSDEV and $S D E V^{2}$ variables are significantly negative and positive respectively when all other independent variables are heldconstant. This outcome offers additional support to the work of DeAngelo and Masulis (1980) and Kale et al (1991) who derived a similar quadratic approximation. Our results in Column 3 of Table 1 show that from 2000 to 2006, the leverage ratio of our typical firm on the Nigerian stock exchange tended to fall with increasingearnings volatility at a ratio of circa 1 to 1 in those years when trading conditions were normal. The relationship became a positive function of roughly 1 to 5during periods of considerable market uncertainty. As we said earlier, the positive relation between business risk and leverage is consistent with the view that the proportion of the expected bankruptcy-related costs in total assets increases significantly in those years when investors are fearful of the general market environment. A rise in relative potential liquidation costs is likely to discourage equity investors in particular from providing finance even to firms with a good credit rating. Such caused the majority of our firms to rely heavily on loans from banks rather than issue underpriced equities. It must be noted that our estimated U-shaped relation between business risk and changes in the total debt ratio is highly sensitive to estimation method, as well as the inclusion of a common group and aggregate time effects.Further research with a larger and more balanced dataset may improve the precision of our estimates.

The other coefficient estimates that are significantly different from zero in Column 3 of Table 1 are for those attributes representing:(i) previous debt ratios, (ii) total operating profit, (iii) agency costs and (iv) asset tangibility. The coefficient of the debt ratio observed in the previous year t-1(DLLEV $\left.V_{t-1}\right)$,shows a significant negative value of minus 0.08 . From the static trade-off theory, this negative correlation indicates that the percentage changes in the debt ratio in the preceding year 2005 were considered to be excessively high, prompting a typical firm to reduce the proportions of borrowing in total assetsin the following year. By contrast, changes in debt ratios observed four years earlier in 2002 were probably considered to be lower than the target level, prompting firms to raise their borrowing ratios over the subsequent four years by an average of 0.25 percentper annum for every 10 percent difference from the overall sample mean leverage. Another argument that is often put forward in support of a positive and significant correlation between past and current period debt levels is related to the risk-signalling theory. According to the signalling hypothesis, the positive coefficient observed for the $D L L E V_{t-4}$ variable may be interpreted as an optimistic gesture by firm managers to their investors in 2002 concerning their assessment of future returns. However, in line with the findings of a study by Alti (2006), our results show that the positive leverage effect of such bogus market signals is short lived, vanishing by 2005. The sum of the coefficients on the lagged debt variables is 0.15 , which suggests an adjustment coefficient of 0.85 . This means that it would take roughly a year and two months $\left(i . . e ., \frac{1 \text { year }}{0.85}=\right.$ 1.18 years $\approx 1$ year and 2 months) for our firm operating under the same management and market conditions as from 2002 to 2006 to return to its target debt ratio once it has deviated from it ${ }^{5}$.The fact that the estimated adjustment factor is positive and close to unity provides evidence that the dynamics implied by our model are not rejected and firms amend their debt ratios relatively quickly, suggesting that the costs of being in disequilibrium are significantly higher than the cost of correcting the imbalance.

The large negative coefficient estimate of minus 0.21 for the attribute representing the percentage change in total operating profit per unit of asset is consistent with the observation of the conventional MyersMajlufpecking order theory that profitable firms often borrow very little, preferring instead to finance potentially beneficial investments with retained earnings. This is partly because such internally generated funds are without transaction and administrative costs. Another reason why retained profit may be the first choice of finance is that by using previously accumulated earnings for investment, managers avoid the discipline and scrutiny associated with a new debt or share offering in the capital market place (Arnold 2008). Then too, the negative relationship between the profitability and leverage of our listed firms is probably related to likelycredit rationing by lending banks during the period of study. The recapitalization policy introduced by the Central

\footnotetext{
${ }^{5}$ The speed with which the disequilibrium was corrected was calculated using the ratio

$\overline{\text { The adjustment coefficient }}$
}

where $n$ is the time period in days, months or years depending on data frequency 
Impact of Business Risk on Corporate Capital Structure of Publicly-Listed Nigerian Companies

Bank of Nigeria in 2004/2005 reduced banks' liquidity position, leading to an increase in interest rates charged on loans. It would seem that our average firm was reluctant to accept such a premium on its debt interest, choosing instead to finance out of retained profit and the possibleissue of equities.

The statistically negative coefficient for the agency costs variable of roughly minus 0.24 is robust to linear and nonlinear functional specifications. A number of previous studies, including the papers by Titman and Wessels (1988), Rajan and Zingales (1995) and Gatchevet al (2008) showed a similar inverse relationship between leverage and agency costs. In explanation, these authors suggested that a rise in the ratio of total sales to total assets (used as our proxy foragency problems) would mean that the management team was efficient in using company assets to generate wealth for shareholders. As a result, the providers of capital, particularlydebtholders, would have little or no reason to restrict the firm's operating freedom and investment flexibility by building complex covenants into the loan agreement. The lower agency costs associated with asset substitution and the underinvestment problems are passed on as a lower risk premium on equity finance in particular. The negative coefficient on the agency cost variable indicates that, on average, the firms in our sample chose to finance throughthe relatively cheaper new stock offering.

The coefficient estimate on the asset tangibility variable DLTAN bears the expected significant positive sign, although the magnitude of between 0.07 and 0.10 varied with whether the leverage model was deemed to be nonlinear or linear. However, we should point out that the size of our estimated slope coefficient for the asset tangibility variable is much lower than the positive figure of between 0.22 and 0.27 normally reported in previous empirical studies. The lower asset tangibility effect on debt ratio annual changes observed for our group of Nigerian listed firms is probably due to the country's ineffective legal system. One manifestation of such weak legal structures is that bankruptcy laws aimed at protecting the interests of lenders are rarely enforced. It often takes years for creditors to take possessionof, and sell collateral assets. Buildings and machinery are left to deteriorate and their collateral value is much diminished in consequence, leaving them with little salvage worth.

\section{Robustness Tests}

There is substantial evidence in the recent literature to suggest that the basic multivariate regressions described in the previous section are restrictive, given that the marginal effect of the explanatory variables may be influenced by their interaction with industry-specific features. The main objective of this section, therefore, is to check the robustness of the results of our quadratic functionto the extra firm attribute relating to industry affiliation.To address this problem, regression 3 which represents our basic multivariate nonlinear model was reestimated for our sub-sample of sixty-two manufacturing firms. The estimated extended or unrestricted model takes the following form.

$$
\begin{gathered}
Y_{i t}=\mu+\alpha\left[D_{i t}\right]+\beta\left[S D E V_{i t}\right]+\theta\left[S D E V_{i t}^{2}\right]+\gamma\left[X_{i t}\right]+\delta[D U M M F]+\omega\left[D U M M F * B R_{i t}\right] \\
+\varepsilon_{i t}-\varepsilon_{i t-1} \ldots \ldots \ldots \ldots \ldots \ldots \ldots \ldots \ldots \ldots \ldots
\end{gathered}
$$

where $D U M M F$ is a dummy variablewhich takes a value of 1 if a firm is in the manufacturing sector and zero otherwise. So if the coefficient $\delta$ ofDUMMFis significantly positive, then the annual borrowing rate of our average manufacturing company is higher than that of its non-manufacturing rival by $\delta$ percent. The interaction $\left[D U M M F * B R_{i t}\right]$ is included to analyse whether the business risk impact on leverage is different across thesub-group of manufacturing and non-manufacturing firms. For instance, if the coefficient $\omega$ on the variable $\left[D U M M F * B R_{i t}\right]$ is significantly positive, then more often than not, an increase in earnings volatilitywill lead to a rise in the debt ratio of our average manufacturing firm by a further $\omega$ percent over and above the value obtained for its non-manufacturing rivals ${ }^{6}$. Column 4 of Table 1 presents the results of our estimation of the unrestricted parameter coefficients $\alpha, \beta, \theta, \gamma, \delta$ and $\omega$ using pooled cross-sectional annual time series data for our ninety-four listed companies over the period 2000-2006 .

The results in Column 4 show a positive and significant value for the intercept differential coefficient $(\delta)$ on the $D U M M F$ variable at the five percent level. This indicates that the percentage increase in the total debt ratio of our average manufacturing firm was higher than the mean changes for our non-manufacturing firms by 18 percent per annum, other factorremaining unchanged. The implied higher rate of borrowing isunsurprising since manufacturing firms, such as automobile, drugs and chemicals, tend to spend heavily on the development of new products and plant by comparison with their counterparts in other sectors. Besides, it is argued by agency cost-based theorists that manufacturing firms with high proportions of marketable tangible assets in prime locations tend to raise more of their required new capital by issuing debt securities beyond the normal target for a typical firm listed on the same stock exchange.

\footnotetext{
${ }^{6}$ The meaning of the other symbols in the equation 5.1 remains as outlined earlier in equation 3.1 . Additionally, Appendix Table A2 provides full definitions of the variables.

${ }^{7}$ We are unable to allow the quadratic effect to vary with industry classification because of data limitation.
} 
The slope coefficient on the interaction variable $[D U M M Y * S D E V]$ is relatively large and bears a significant negative sign. It suggests that that a one percent increase in business risk in normal times, will lead our average manufacturing firm to cut its debt ratio by an extra 10.39 percent per annum over and above the yearly percentage fall observed for our non-manufacturing sub-sample. There are three plausible explanations for the exaggerated drop in the gearing ratio for our manufacturing sector. First, manufacturing firms tend to have a relatively high proportion of fixed to variable costs. Companies with high fixed assets also have high potential liquidation and re-organisation costs relative to total assets and so are less able to cope with uncertainties in their projectedcashflows. Second, the demand for manufactured products and input costs is highly uncertain. But although the further risk posed by such variability in demand and price of production inputs can be controlled by buying futures contracts and other derivative instruments, the market for such hedging techniques is underdeveloped in emerging markets including Nigeria. Third,manufacturing firms tend to be more innovative and so to have more profitable investment opportunities. They therefore need to maintain a greater reserve in their borrowing capacity than firms in other sectors.

The estimates in the extended models in Columns 4indicate that the coefficient on the autonomous business risk variable $(\beta)$ maintained its negative sign and statistical significance.However, its size is highly sensitive to the joint inclusion of the manufacturing intercept and slope dummies; rising to minus 3.51 percent. The implication of a simultaneous addition of the industry intercept and slope dummies, it seems, is to quadruplethe decreasing leverage effect of earnings variability. The estimated coefficient $(\theta)$ on the $\left(S D E V^{2}\right)$ variable continues to bear a positive sign, going up to plus 21.65 in Column 4.

The results for the other control variables in the extend models in Columns 4 of Table 1 are broadly similar to those of our findings in the restricted quadratic specification in Column 3 with one notable exception. The coefficient on the asset tangibility variable reverted to a significant negative value of minus 0.025 . We may therefore infer that the tangible assets being referred to in our regressionsare probablymanufacturing plant and equipment which are illiquid, expensive to transport and to modify to suit the needs of any new owner. This reduces their collateral value and so discourages our average manufacturing firm from pushing its use of debt to what it otherwise might have been.

A partial differentiation of regression 4 with respect to the earnings risk variable $(S D E V)$ indicates that an increase in earnings risk by one percent will raise the annual percentage change in the total leverage ratio of an average manufacturing firm in our sample by 35 percent in the long-run. This is almost three times the average rate of 12percent a year reported in regression 3 for our standard non-manufacturing firms.The inclusion of the manufacturing intercept and slope differentials are clearly necessary and their exclusion in previous capital structure models represent a specific example of omitted variable bias.

\section{Conclusions And Policy Recommendations}

This paper has investigated the role of business risk in determining the capital structure choices of a panel of ninety-four Nigerian listed firms from 2000 to 2006. It has contributed to the empirical literature on the topic by focusing on the dynamics of the leverage ratios of companies operating in Africa's most populous and its most corrupt country. Its findings will shed further light on the empirical determinants of target capital structure and the rate of adjustment toward an optimal level for firms in oil-dependent emerging markets. Additionally, as far as we can tell, this paper is the first to employ the quadratic function derived by Kale et al (1991) to show thatthe relationship between business risk and capital structure in an emerging market economy is roughly U-shaped.

On the whole, the findings from our extended dynamic panel data framework generally support a Ushaped prediction of a quadratic association between changes in business risk andthe total debt ratio of a typical Nigerian listed firm. It is estimated that in ordinary times, our average firm will cut its rate of borrowing relative to total assets by between 1 and 4 percent for every one percentage point increase in its business risk. By contrast, in those years when equity investors are particularly nervous about the general market outlook, an increase in business risk will lead our average Nigerian firm to raise the proportion of total debt liabilities in its capital structure by between 5 and 22 percent.This suggests that policies which lower the (i) probability of company failure, (ii) deadweight of bankruptcy costs that must be absorbed by investors in the event of insolvency and/or (iii) increase the market value of the firm's assets will help mitigate the rise in the equity risk premium and discourage unnecessary borrowing. Three policies which might facilitate the achievement of these goals may be summarized as follows:

First, the government needs to implement policies aimed at increasing the depth and efficiency of the market so as to "correctly" price shares. Such market-orientated reforms involve initiatives which will encourage a greater openness and private sector participation in the economy.Then too, policies should be introduced to automate tradingon the stock exchange as well as to educate all registered asset managers on the linkages between risk and expected returns. Moreover, agency costs arising from the conflicts of interest between managers and external providers of finance can be mitigated by setting up regulatory bodies with legal powers to enforce the rights of investors. Additionally, an independent arbitration agency should be set up to 
Impact of Business Risk on Corporate Capital Structure of Publicly-Listed Nigerian Companies

settle disputes between firms and their employees, together with an ombudsman who deals with complaints by customers, suppliers and other companies. Furthermore, regulations that ensure that firms publish timely and accurate information in their accounts, as well as the provision of competent and trusted auditors, will help reduce the potential costs of financial distress for external investors.

Second,policies which createan appropriate enabling macroeconomic environment will help our firms identify and invest in profitable long-term projects and hence increase the potential market value of their assets.To this end, the Government should persist with the implementation of appropriate fiscal and monetary policies allied to the debt-restructuring programme originally agreed with the IMF in 2002. Such budgetary adjustments may relate to the de-regulation of prices as well as privatization and cuts in public enterprise subsidies. Monetary reforms which will enhance the capacity ofNigerian firms to generate higher profits will include those aimed at lowering high inflationary pressures, the appreciation of real exchange rates and the reduction of inefficiency within the banking sector. A major impediment to economic growth and associated profits for Nigerian companies is corruption and bureaucracy. To fight corruption, the Government should introduce measures aimed at simplifying controls. Further, efforts to enhance transparency in procedures for public contracts, civil service employment, customs, border controls, tax systems and the activities of the police will reduce the necessity for people to pay bribes to government officials.Then too, initiatives to develop credible legal structures for dealing with corrupt practices by public sector workers in particular should be put in place. To this end, the Economic and Financial Crime Commission (EFCC), which has been set up to deal with corruption, is a step in the right direction, but how effective it will be, we do not yet know.

Finally, policies which encourage entrepreneurial initiatives and efficiency within the manufacturing sector in particular will help arrest the dramatic increase in their borrowing rates as predicted in our extended model. Initiatives which aim to remove bias in tax codes that favour high leverage and risky-ventures will help in the development of the manufacturing sector. In addition,an independent body should be set up to scrutinize high leverage projects to ensure that the potential beneficial effects of debt finance are not offset by the potential costs of impending insolvency.Moreover, action should be taken to encouragemanufacturing firms to limit their vulnerability to domestic trading conditions byexporting an increasing proportion of their output.Appropriate export expansion policies require that the Nigerian Government tackle problems relating to the poor quality of infrastructure, especially where it specifically bears upon the cost of production and transport of goods. These facilities include roads and railways, power, telecommunications, ports and airports in particular. Other constraints which restrict the growth of manufactured exports may include the limited availability of appropriately skilled labour, as well as an absence of law and order and a poor protection of property. Improvements therein should attract foreign direct investment and expose local producers to international best practice in production and capital management. To encourage diversification, exporters of non-traditional agricultural products, such as cut-flowers, medicinal plants and exotic fruit and vegetables, should, perhaps, be given duty-free access to imported inputs, including seeds, fertilizers, capital machinery and spare parts. Further regional market integration together with monetary union would also allow Nigerian firms to take advantage of economies of scale and so to improve their export competitiveness.

\section{References}

[1] Alti, A (2006), “How Persistent Is the Impact of Market Timing on Capital Structure?”,The Journal of Finance, Vol. 61 (4), pp. $1681-1710$

[2] Arnold, G (2008),Corporate Financial Management, $4^{\text {th }}$ Edition, (FT Prentice Hall)

[3] Asteriou, D., and S. Hall (2007), Applied Econometrics: A Modern Approach, Revised edition (Palgrave Macmillan, New York)

[4] Attanasio, O., L. Picci, and A. Scorcu (2000), "Saving, Growth and Investment: A Macroeconomic Analysis Using A Panel of Countries", Review of Economics and Statistics, Vol. 82, No. 2, pp. 182-211.

[5] Auerbach, A.J (1985), "Real Determinants of Corporate Leverage", in Friedman (ed.), Corporate Capital Structure in the United States(University of Chicago Press, Chicago).

[6] Berger, A.N (1995a), "The Relationship Between Capital and Earnings in Banking” Journal of Money, Credit and Banking, Vol. 27 (2) pp. 432-456

[7] Berger, A.N (1995b), "The Profit-Structure Relationship in Banking-Tests of Market-Power and Efficient-Structure Hypotheses." Journal of Money, Credit, and Banking, Vol.27, pp. 404-31.

[8] Bevan, A.A., and J. Danbolt (2002), "Capital Structure and its Determinants in the UK - a Decompositional Analysis, Applied Financial Economics, Vol. 12 (3), pp. 159-170

[9] Bhaduri, S.N (1996), "Determinants of Capital Structure Choice: a Study of the Indian Corporate Sector", Applied Financial Economics, Vol. 12(9), pp.655-665

[10] Booth, L., V. Aivazian., V. Demirguc-Kunt., and V.Maksimovic (2001). "Capital Structures in Developing Countries", Journal of Finance, 56, 87- 130 .

[11] Bowen, R.M., L.A. Daley., and C.C. Huber (1982), "Evidence on the Existence and Determinants of Inter-Industry Differences of Leverage", Financial Management, Vol.11, pp. 10-20.

[12] Bradley, M., A. Jarrell., and E. Kim (1984), "On the Existence of an Optimal Capital Structure: Theory and Evidence", Journal of Finance, Vol. 39, pp. 857-80.

[13] Brigham, F.E., and M.C. Ehrhardt (2005),Financial Management: Theory and Practice, $11^{\text {th }}$ Edition, (South-Western Cengage Learning)

[14] Castanias, R(1983),“Bankruptcy Risk and Optimal Capital Structure”, Journal of Finance 38, 1617-1635. 
[15] Chen, J.J (2003), "Determinants of Capital Structure of Chinese-listed Companies", Journal of Business Research, Vol.57, pp. $1341-1351$

[16] Chui, A.C.W., A.E. Lloyd.,C.C.Y. Kwok (2002), "The Determinants of Capital Structure: Is National Culture a Missing Piece to the Puzzle?"Journal of International Business Studies 2002; 33(1):99-128.

[17] Chung, K.H. (1993), "Asset Characteristics and Corporate Debt Policy: An Empirical Test", Journal of Business Finance \& Accounting, Vol. 20 (1), pp. 83-98.

[18] CIA-The World Fact Book-Nigeria (2010),https://www.cia.gov/library/publications/the-world-factbook/geos/ni.html: Accessed on the $31^{\text {st }}$ of August 2010

[19] DeAngelo, H., and R.W. Masulis (1980), “Optimal Capital Structure Under Corporate and Personal Taxation”, Journal of Financial Economics, Vol. 8, pp.3-29.

[20] Ferri, M.G., and W.H. Jones (1979), "Determinant of Financial Structure: A New Methodological Approach”, Journal of Finance, Vol. 34, pp. 631-44.

[21] Flath, D., and C. Knoeber(1980), "Taxes, Failure Costs, and Optimal Industry Capital Structure: An Empirical Test”,Journal of FinanceVol.35, pp. 99-117.

[22] Frank, M.Z., and Goyal,V.K (2003),“Testing the Pecking Order Theory of Capital Structure”,Journal of Financial Economics, Vol. 67, pp. 217-248.

[23] Frank, M.Z., and Goyal, V.K (2004), "The Effect of Market Conditions on Capital Structure

[24] Adjustment",Finance Research LettersVol.1, pp. 47-55

[25] Gatchev, V., P.A. Spindt., and V. Tarhan (2008), "How Do Firms Finance Their Investments?:The Relative Importance of Equity Issuance and Debt Contracting Costs, Journal of Corporate Finance, Vol.15 (2), pp.179-195

[26] Greene, W (2002),Econometric Analysis, $5^{\text {th }}$ Edition (London: Prentice Hall).

[27] Harris, M., and A. Raviv (1990), "Capital Structure and the Informational Role of Debt”, Journal of Finance, Vol. 45, pp. 321-49.

[28] Harris, M., and A. Raviv(1991),“The Theory of Capital Structure”, Journal of finance, Vol.46, 297-351.

[29] Hsiao, C (2003), Analysis of Panel Data, $2^{\text {nd }}$ Edition (Cambridge: Cambridge University Press).

[30] Hodder, J.E., and L.W. Senbet (1990), “International Capital Structure Equilibrium”,Journal of Finance,Vol. 45(5), pp. 1495 1516.

[31] Homaifar, G., J. Zietz., and O. Benkato (1994), "An Empirical Model of Capital Structure: Some New Evidence", Journal of Business Finance \& Accounting, Vol. 21,(1), pp. 1-14

[32] Huang, G., and F.M. Song (2006), "The Determinants of Capital Structure: Evidence from China", China Economic Review, Vol. $17, \mathrm{pp} .14-36$

[33] James, C (1991),"The Losses Realized in Bank Failures."Journal of Finance, Vol. 46, pp. 1223-42.

[34] Jalilvand, A., and R.S. Harris (1984), "Corporate Behaviour in Adjusting to Capital Structure and Dividend Targets: An Econometric Study", Journal of Finance, Vol. 39, pp.127-45.

[35] Kale, J., T. H. Noe, and G.G. Ramìrez (1991), "The Effect of Business Risk on Corporate Capital Structure: Theory and Evidence", Journal of Finance, Vol. 46 (5), pp. 1693-1715

[36] Kester, C.W. (1986), "Capital and Ownership Structure: A Comparison of United States and Japanese Manufacturing Corporations", Financial Management, Vol. 15, pp. 97-113.

[37] Long, M.,and I. Malitz (1985), "The Investment Financing Nexus: Some Empirical Evidence", Midland Corporate Finance Journal, Vol. 3, pp. 53-59.

[38] Marsh, P (1982), “The Choice Between Debt and Equity: An Empirical Study”, Journal of Finance, Vol. 37, pp. 121-44.

[39] Masulis, R (1988), The Debt-equity Choice, (Ballinger Publishing Co., Cambridge, MA).

[40] Mikkelson, W., (1984), “Discussion: On the Existence of Optimal Capital Structure: Theory and Evidence”, Journal of Finance, Vol.39, pp. 878-880

[41] Mukherjee, C., H. White., and M. Wuyts (1998),Econometrics and Data Analysis for Developing Countries, Routledge, London and New York

[42] Modigliani, F. and M.H. Miller (1958), "The Cost of Capital, Corporation Finance and the Theory of Investment", American Economic Review, Vol. 48,pp. 261-97.

[43] Modigliani, F., and M.H. Miller (1963), "Corporate Income Taxes and the Cost of Capital: A Correction", American Economic Review, Vol.53, pp.433-433

[44] Myers, S.C (1984), "The Capital Structure Puzzle", Journal of Finance, Vol. 39, pp. 575-92.

[45] Myers, S.C., and N.S. Majluf (1984), "Corporate Financing and Investment Decisions When Firms Have Information that Investors Do Not Have", Journal of Financial Economics, Vol. 13, pp. 187-221.

[46] Myers, S. C. (2003),Financing of Corporations in G. M. Constantinides, M. Harris, \& R. Stulz (Eds.), Handbook of the economics of finance, pp. 215-253,(Elsevier B.V).

[47] Ozkan, A. (2001), "Determinants of Capital Structure and Adjustment to Long Run Target: Evidence from UK Company Panel Data", Journal of Business Finance \& Accounting, 28(1) \& (2),pp. 175-198

[48] RajanR.G., and L. Zingales(1995), "What Do We Know About Capital Structure? Some Evidence from International Data", Journal of Finance, Vol. 50, pp.1421-60,

[49] Shyam-Sunder, L., and S.C. Myers (1999), “Testing Static Trade-off Against Pecking Order Models of Capital Structure”, Journal of Financial Economics, Vol. 51, pp. 219-44

[50] Taggart, R.A (1977), “A Model of Corporate Financing Decisions”, Journal of Finance, Vol. 32, pp. 1467-84

[51] Titman, S., and R. Wessels (1988), "The Determinants of Capital Structure Choice”, Journal of Finance, Vol. 43, pp. 1-19.

[52] Wald, J. K (1999), “How Firm Characteristics Affect Capital Structure: An International Comparison”,Journal of Financial Research, 22(2), 161-187.

[53] Wanzenried, G(2006), Capital structure dynamics in the UK and Continental Europe,European Journal of Finance 12, 693-716.

[54] Wiwattanakantang, Y. (1999), "An Empirical Study on the Determinants of the Capital Structure of Thai firms", Pacific-Basin Finance Journal, Vol.7, 371-403.

[55] Wolfgang, D., and G.Wanzenried (2006), “What determines the speed of adjustment to the target capital structure?",Applied Financial Economics, Vol.16 (13), pp. $941-958$ 
Impact of Business Risk on Corporate Capital Structure of Publicly-Listed Nigerian Companies Appendix Table A1: Table A1: Leverage Ratio Of Nigerian Listed Firms And Its Major Determinants: Descriptive Statistics From 2000 To 2006

\begin{tabular}{|c|c|c|c|c|c|}
\hline Items & & $\begin{array}{l}\text { Mean } \\
(\%)\end{array}$ & $\begin{array}{l}\text { Standar } \\
d \\
\text { deviatio } \\
n \\
(\%)\end{array}$ & $\begin{array}{l}\text { Pairwise } \\
\text { correlatio } \\
n \\
\text { coefficien } \\
t\end{array}$ & $\begin{array}{l}\text { T-test } \\
(p- \\
\text { value })\end{array}$ \\
\hline 1 & $\begin{array}{l}\text { Total liability \% total assets (total leverage } \\
\text { ratio) }\end{array}$ & & & & \\
\hline $\mathrm{a}$ & A Panel of ninety-four listed firms & 37.51 & 19.83 & $-0.272 * * *$ & \\
\hline $\mathrm{b}$ & A Panel of sixty-two manufacturing firms & 38.26 & 19.57 & $-0.310 * * *$ & 0.607 \\
\hline 2 & Change in total leverage ratio & & & & \\
\hline $\mathrm{a}$ & A Panel of ninety-four listed firms & 11.18 & 65.09 & 1.00 & \\
\hline $\mathrm{b}$ & A Panel of sixty-two manufacturing firms & 7.10 & 48.55 & 1.00 & $0.030 * *$ \\
\hline 3 & $\begin{array}{l}\text { Standard deviation of the ratio of EBDIT to } \\
\text { total asset (business risk) }\end{array}$ & & & & \\
\hline $\mathrm{a}$ & A Panel of ninety-four listed firms & 15.50 & 7.09 & -0.062 & \\
\hline $\mathrm{b}$ & Manufacturing companies & 14.98 & 6.37 & -0.068 & 0.895 \\
\hline 4 & $\begin{array}{l}\text { Change in total Sales \% total assets } \\
\text { (Agency cost) }\end{array}$ & & & & \\
\hline $\mathrm{a}$ & A Panel of ninety-four listed firms & -7.46 & 13.46 & -0.060 & \\
\hline $\mathrm{b}$ & Manufacturing companies & -10.05 & 13.88 & -0.043 & 0.521 \\
\hline 5 & $\begin{array}{l}\text { Change in total fixed assets \% total assets } \\
\text { (Tangibility) }\end{array}$ & & & & \\
\hline $\mathrm{a}$ & A Panel of ninety-four listed firms & 9.22 & 47.99 & $0.276 * * *$ & \\
\hline $\mathrm{b}$ & Manufacturing companies & 7.45 & 45.24 & $0.142 * * *$ & 0.923 \\
\hline 5 & $\begin{array}{l}\text { Change in EBDIT \% total assets } \\
\text { (Profitability) }\end{array}$ & & & & \\
\hline $\mathrm{a}$ & A Panel of ninety-four listed firms & -29.96 & 21.06 & 0.009 & \\
\hline $\mathrm{b}$ & Manufacturing companies & -19.45 & 17.34 & -0.045 & 0.414 \\
\hline 6 & $\begin{array}{l}\text { Change in total sale revenue millions of } \\
\text { Naira (Size) }\end{array}$ & & & & \\
\hline $\mathrm{a}$ & A Panel of ninety-four listed firms & 11.39 & 62.13 & -0.011 & \\
\hline $\mathrm{b}$ & Manufacturing companies & 12.13 & 40.15 & 0.079 & 0.090 \\
\hline 7 & Change in total assets (Growth prospects) & & & & \\
\hline $\mathrm{a}$ & A Panel of ninety-four listed firms & 20.30 & 36.28 & $0.233 * * *$ & \\
\hline $\mathrm{b}$ & Manufacturing companies & 19.63 & 35.07 & $0.187 * * * *$ & $\begin{array}{l}0.000 * * \\
*\end{array}$ \\
\hline
\end{tabular}

Notes: 1. EBIT is a measure of earnings before depreciation, interest and tax

2. Percentage change in all the variables is estimated as the first difference in the natural logarithm of the series in question.

3. $* * *$ and $* *$ indicate that coefficient is significant at one and five percent confidence level

Appendix Table 2: The Definitions of Variables

\begin{tabular}{|l|l|}
\hline$L E V$ & $\begin{array}{l}\text { The total leverage ratio. This is calculated as the ratio of total liabilities to } \\
\text { total assets }\end{array}$ \\
\hline$D L L E V_{t-1}$ & $\begin{array}{l}\text { Percentage change in the natural logarithm of the total leverage ratio lagged } \\
\text { one year, } \mathrm{t}-1\end{array}$ \\
\hline$D L L E V_{t-2}$ & $\begin{array}{l}\text { Percentage change in the natural logarithm of the total leverage ratio lagged } \\
\text { two years, } \mathrm{t}-2\end{array}$ \\
\hline$D L L E V_{t-3}$ & $\begin{array}{l}\text { Percentage change in the natural logarithm of the total leverage ratio lagged } \\
\text { three years, } \mathrm{t}-3\end{array}$ \\
\hline$D L L E V_{t-4}$ & $\begin{array}{l}\text { Percentage change in the natural logarithm of the total leverage ratio lagged } \\
\text { four years, } \mathrm{t}-4\end{array}$ \\
\hline$S D E V$ & $\begin{array}{l}\text { The standard deviation of the ratio of earnings before depreciation, interest } \\
\text { and tax to total assets. An increase in this variable denotes a worsening in } \\
\text { earning volatility (i..., business risk) }\end{array}$ \\
\hline$S D E V_{t-1}$ & $\begin{array}{l}\text { The standard deviation of the ratio of earnings before depreciation, interest } \\
\text { and tax to total assets lagged one year, } \mathrm{t}-1\end{array}$ \\
\hline$S D E V_{t-2}$ & $\begin{array}{l}\text { The standard deviation of the ratio of earnings before depreciation, interest } \\
\text { and tax to total assets lagged two years, } \mathrm{t}-2\end{array}$ \\
\hline
\end{tabular}


Impact of Business Risk on Corporate Capital Structure of Publicly-Listed Nigerian Companies

\begin{tabular}{|l|l|}
\hline$S D E V_{t-3}$ & $\begin{array}{l}\text { The standard deviation of the ratio of earnings before depreciation, interest } \\
\text { and tax to total assets lagged three years, } \mathrm{t}-3\end{array}$ \\
\hline$S D E V_{t-4}$ & $\begin{array}{l}\text { The standard deviation of the ratio of earnings before depreciation, interest } \\
\text { and tax to total assets lagged four years, } \mathrm{t}-4\end{array}$ \\
\hline$S D E V^{2}$ & $\begin{array}{l}\text { The square of the standard deviation of the ratio of earnings before } \\
\text { depreciation, interest and tax to total assets }\end{array}$ \\
\hline PROFITABILITY & $\begin{array}{l}\text { The ratio of earnings before depreciation, interest and tax (EBDIT) to total } \\
\text { assets }\end{array}$ \\
\hline TANGIBILITY & The ratio of total fixed assets to total assets \\
\hline GROWTH & $\begin{array}{l}\text { Percent change in the natural logarithm of total assets in millions of Nigerian } \\
\text { Naira }\end{array}$ \\
\hline AGENCY COST & $\begin{array}{l}\text { The ratio of total sales to total assets } \\
\text { SIZE }\end{array}$ \\
\hline$D U M M F$ & $\begin{array}{l}\text { Percentage change in the natural logarithm of total sales revenue in millions } \\
\text { A dummy variable which take a value of 1 for companies classified as } \\
\text { manufacturing under the United Nations Standard Industrial Classification } \\
\text { Code (SIC). }\end{array}$ \\
\hline$D U M M *^{*} S D E V$ & $\begin{array}{l}\text { A slope dummy variable calculated as the product of the manufacturing } \\
\text { dummy variable and the earnings volatility indicators. }\end{array}$ \\
\hline
\end{tabular}

